\title{
PENGARUH PENDIDIKAN FORMALDAN PELATIHAN TERHADAP KINERJAAMIL ZAKAT DI KOTA KENDARI \\ (Studi pada Kecamatan Puwatu, Kecamatan Wawombalata dan Kecamatan Abeli di kota kendari)
}

\author{
Wahyuniati \\ Hamid
}

\begin{abstract}
Abstarct: This research aims to know the effect of formal education and training toward the performance of Amil Zakat in Kendari. The data collecting method used questionnare. The Sample consisted of 44 respondents. Based on the result of statistic analyst test found that there were an effect of the formal education and training toward the performance of Amil Zakat in Kendari while the simultaneous test result used $\mathrm{F}_{\text {test }} 92,892$ and $\mathrm{F}_{\text {sig }}$ $0,000<\alpha=0,05$. In other words, Formal Education $\left(X_{1}\right)$ which are religion education and general education, and Training $\left(\mathrm{X}_{2}\right)$ which the material are execution time, and tutor, simultaneously have significant effect toward the performance of Amil Zakat (Y) on trusty level 95\%.
\end{abstract}

Keywords: Formal Education,Training, and Performance

Indonesia merupakan negara yang memiliki penduduk muslim terbesar di dunia dan menyebar hampir merata di seluruh wilayah provinsi dan kabupaten/kota, termasuk Kota Kendari. Zakat merupakan salah satu instrumen yang disyariatkan dalam Islam sebagai sumber dana pembangunan kesejahteraan ummat, yang juga memiliki potensi yang cukup besar dalam pembangunan ekonomi masyarakat, apabila pendistribusiannya dilakukan dengan baik dan benar oleh pengelola. Akan tetapi potensi yang dimiliki oleh zakat dapat saja tidak terdistribusi dengan baik apabila dalam pendistribusiannya dilakukan dengan cara yang kurang baik atau tidak sesuai dengan aturan yang telah ditetapkan. Untuk itu dalam pencapaian fungsi zakat itu sendiri sebagai sumber dana pembangunan kesejahteraan ummat diperlukan pengelolaan yang cermat dan tanggung jawab penuh oleh para pengelola dalam hal ini Amil Zakat.

Hasil studi Badan Amil Zakat Nasional (BAZNAS) 2012 kerjasama dengan Fakultas Ekonomi dan Manajemen IPB, mengemukakan potensi zakat nasional berdasarkan data SUSENAS adalah sekitar Rp. 217 triliun, sedangkan untuk Kota Kendari berdasarkan data PDBR 2010 diperoleh potensi zakat sebesar Rp.174.237.234900, (Samdin, 2012). Potensi ini jika terakumulasi dapat mengentaskan kemiskinan di Kota Kendari dalam satu tahun. Potensi zakat ini dapat terakumulasi jika para amil menjalankan tugasnya sebagaimana mestinya.
Potensi zakat yang ada di kota Kendari cukup untuk membantu ekonomi masyarakat di kota Kendari bahkan jika seluruh potensi dana zakat yang bisa digali di kota Kendari terealisasi, akan mampu mengentaskan kemiskinan yang ada, akan tetapi fenomena yang terjadi saat ini dana zakat yang ada bahkan tidak terdistribusi dengan baik disebabkan oleh berbagai hal yang tidak terhindarkan dalam proses pendistribusiannya, yang bisa saja terjadi karena amil belum memahami peran dan fungsinya serta belum mengerti tentang perhitungan dan pembagian zakat yang sebenarnya karena belum pernah menempuh pendidikan secara spesifik tentang zakat itu sendiri padahal halhal demikian sangat mempengaruhi efektifitas penyaluran dana zakat tersebut. Serta banyaknya Amil yang bertugas, tetapi belum menguasai segala aspek dalam zakat, kepada siapa saja dana zakat seharusnya diberikan dan bagaimana proses penyalurannya karena kurang berpengalaman dan belum memahami keadaan masyarakat juga belum mengetahui secara pasti potensi zakat yang ada di masyarakat sehingga pelatihan untuk seorang Amil sangat dibutuhkan, karena bisa menjadi alternatif pemberian pemahaman yang lebih terperinci, agar amil dapat memahami secara pasti tugas serta perannya.

McDonald (1996) mengemukakan bahwa "Education is a process aran activity which is directed at producing desirable changes in the behavior of human being." pendidikan adalah suatu proses 
atau aktivitas yang secara langsung diharapkan dapat menghasilkan perubahan tingkah laku. Pendidikan formal merupakan proses menempuh pengetahuan melalui lembaga-lembaga formal yang telah ditetapkan baik itu kurikulum pendidikannya, tingkat pendidikannya, dan tenaga pengajar yang disesuaikan dengan kebutuhan anak didik. Pendidikan formal dengan berbagai programnya mempunyai peranan penting dalam proses memperoleh dan meningkatkan kualitas kemampuan profesional individu. Melalui pendidikan formal ini seseorang dipersiapkan untuk memiliki bekal agar siap tahu, mengenal dan mengembangkan metode berpikir secara sistematik agar dapat memecahkan masalah yang akan dihadapi dalam kehidupan dikemudian hari (Sedarmayanti, 2001). Pendidikan merupakan salah satu syarat utama untuk seseorang dalam membentuk individu yang paham terhadap situasi dan mampu untuk melakukan sesuatu, sebab dalam pendidikan itu sendiri terjadi proses pengembangan diri yang akan membuat seseorang dari tidak tahu menjadi tahu, seorang amil haruslah menempuh pendidikan mengenai tugasnya itu, yang bisa didapatkan dengan menempuh pendidikan formal, sebab untuk memahami semua dimensi yang terkandung dalam zakat membutuhkan proses serta waktu yang tidak sedikit, dengan demikian pendidikan adalah faktor yang sangat penting bagi seorang Amil untuk menunjang kinerjanya dimasa mendatang. Pendidikan Formal merupakan suatu pendidikan yang mendasar yang dilakukan melalui jalur sekolah.

Pelatihan dapat berpengaruh terhadap kinerja seorang Amil zakat, dimana pelatihan merupakan suatu kegiatan pembelajaran yang terprogram dengan tujuan untuk meningkatkan kemampuan dan keterampilan peserta pelatihan. Dengan menjalani pelatihan yang sesuai, amil yang sedang menjalankan tugasnya akan mendapatkan pengetahuan yang lebih baik lagi yang secara langsung dapat berdampak pada kinerjanya selama pelatihan yang diberikan benarbenar mengena dengan kondisi Amil saat ini. Di Kota Kendari khususnya, Departemen Agama bekerja sama dengan Badan Amil Zakat Daerah (BAZDA) telah beberapa kali mengadakan Pelatihan khususnya mengenai dimensi zakat yang didalamnya termasuk mengenai kinerja Amil yang diikuti oleh Amil zakat yang berdomisili diKota Kendari, pelatihan yang biasanya dilakukan pada saat menjelang bulan suci Ramadhan ini disambut baik oleh para Amil karena dapat secara langsung memberikan pengarahan, terutama untuk pembayaran Zakat Fitrah yang wajib dibayarkan oleh ummat Muslim pada bulan Ramadhan. Meski demikian pada Pelatihan tersebut Departemen Agama selaku pelaksana Pelatihan tidak hanya membahas secara spesifik mengenai Zakat fitrah saja, tetapi membahas secara keseluruhan mengenai Zakat, yang terrangkum dalam dimensi zakat.

Kinerja seseorang merupakan kombinasi dari kemampuan, usaha, dan kesempatan yang dapat dinilai dari hasil kerjanya.Sebagai mana termaktub dalam Firman Allah SWT dalam Al-Qur an: "Dan carilah pada apa yang telah dianugerahkan Allah kepadamu kebahagiaan akhirat dan janganlah kamu melupakan bagianmu dari kenikmatan duniawi. Dan berbuat baiklah kepada orang lain sebagaimana Allah telah berbuat baik kepadamu, karena sesungguhnya Allah tidak menyukai orang-orang yang berbuat kerusakan" (QS.Al-Qashash:77). Hadits yang disampaikan oleh Rasulullah SAW, Artinya: "Bekerjalah untuk kepentingan duniamu seolah-olah kamu hidup selama-lamanya. Dan bekerjalah untuk akhiratmu seolah-olah kamu mati esok pagi”.

Sudah menjadi kewajiban bagi manusia sebagai mahluk yang memiliki banyak kebutuhan dan kepentingan dalam kehidupannya untuk bekerja guna memenuhi segala kebutuhannya tersebut. Seorang muslim harus menyeimbangkan antara kepentingan dunia dan akhirat. Tidak hanya berorientasi pada kepentingan akhirat saja, seorang muslim juga harus memikirkan kepentingan duniawi. Untuk menyeimbangkan kehidupan dunia dan akhirat tersebut, maka wajib bagi seorang muslim untuk bekerja. Bekerja adalah kodrat hidup, baik kehidupan spiritual, intelektual, fisik biologis, maupun kehidupan individual dan sosial dalam berbagai bidang. Karena itu, agar manusia benar-benar "hidup" dalam kehidupan ini ia memerlukan ruh (spirit). Untuk ini, Al-qur an diturunkan sebagai "ruhan min amrina", yakni spirit hidup ciptaan Allah, sekaligus sebagai "nur" (cahaya) yang tak kunjung padam, agar kehidupan manusia tidak tersesat. Dalam Al-qur an dan Al-hadits banyak ditemukan literatur yang memerintahkan seorang muslim untuk bekerja dalam memenuhi dan melengkapi kebutuhan dunianya.

Kinerja Amil, sangat menentukan penggunaan dana zakat yang diharapkan mampu membantu dan meningkatkan taraf hidup masyarakat sehingga dapat tercapai tujuan zakat yang sebenarnya, sejauh mana usaha para Amil dalam proses mengidentifikasi warga yang membutuhkan, ketepatan dalam penyaluran dana zakat sehingga dana tersebut benar-benar sampai kepada sasaran. Mohrman (2002), mengemukakan 
bahwa: "A performance consists of a performer engaging in behavior in a situation to achieve results". Dari pendapat ini, terlihat bahwa kinerja dilihat sebagai suatu proses bagaimana sesuatu dilakukan. Jadi, pengukuran kinerja dilihat dari baik tidaknya aktivitas kerja tertentu untuk mendapatkan hasil yang diinginkan. Ini menunjukan bahwa amil dengan kinerja yang baik dapat dilihat dari proses ia bekerja, apa saja yang dilakukannya untuk menghasilkan sesuatu yang diharapkan. Amil dengan Kinerja yang tinggi mampu untuk melakukan aktifitas kerja tertentu yang nantinya akan berpengaruh terhadap hasil kerjanya, dan diharapkan mampu untuk merealisasikan tujuan dari zakat itu sendiri yakni membantu masyarakat yang membutuhkan dan mengentaskan kemiskinan, juga dapat berpengaruh positif pada amil itu sendiri.

Berdasarkan penjelasan diatas dapat diketahui bahwa pendidikan merupakan faktor penting dalam pelaksanaan kinerja seorang amil, khususnya pendidikan formal sebelum terjun kepekerjaannya nanti, seorang amil harus paham apa saja dimensi dalam zakat, dan harus mengetahui tugas-tugasnya. Selain itu pelatihan juga menentukan sejauhmana pemahaman amil terhadap dimensi zakat dan memberikan tambahan pengetahuan untuk menyel esaikan masalahmasalah yang terjadi selama amil menjalankan tugas, sebab melihat dari fenomena yang ada zakat ini belum terealisasi dengan baik sesuai dengan tujuannya, pelatihan juga menjadi ajang pertukaran ilmu bagi para amil lainnya dalam pelaksanaan tugas. Sehingga kedua hal tersebut sangat berpengaruh terhadap kinerja amil, dan sesuai dengan tujuan yang diharapkan. Sehubungan dengan hal tersebut maka tujuan penelitian ini untuk mengetahui pengaruhPendidikan formal dan Pelatihanterhadap kinerja Amil Zakat di Kota Kendari.

\section{Zakat}

Metwally (1995), menggatakan bahwa zakat adalah pajak yang dikumpulkan dari orang kaya muslim yang diperuntukkan terutama untuk membantu masyarakat muslim yang miskin.Menurut HR. AtTirmidzi, zakat berarti: tumbuh, berkembang; kesuburan atau bertambah atau dapat pula berarti membersihkan atau mensucikan, dan Menurut Hukum Islam, zakat adalah nama bagi suatu pengambilan tertentu dari harta yang tertentu, menurut sifat-sifat yang tertentu dan untuk diberikan kepada golongan tertentu pula.
Zakat terbagi atas dua macam yaitu Zakat Fitrah yang artinya adalah zakat diri yang diwajibkan atas diri setiap individu lelaki dan perempuan muslim yang berkemampuan dengan syarat-syarat yang ditetapkan. Kata "Fitrah" yang ada merujuk pada keadaan manusia saat baru diciptakan sehingga dengan mengeluarkan zakat ini manusia dengan izin Allah akan kembali fitrah. Dan yang kedua adalah Zakat Mall atau zakat harta.

\section{Amil Zakat}

Amil zakat adalah semua pihak yang bertindak mengerjakan sesuatu yang berkaitan dengan pengumpulan, penyimpanan, penjagaan, pencatatan, dan penyaluran atau distribusi harta zakat yang dikenal dengan dimensi zakat. Mereka diangkat oleh pemerintah dan memperoleh izin darinya atau dipilih oleh instansi pemerintah yang berwenang atau oleh masyarakat Islam untuk memungut dan membagikan serta tugas lain yang berhubungan dengan zakat, seperti penyadaran atau penyuluhan masyarakat tentang hukum zakat, menerangkan sifat-sifat pemilik harta yang terkena kewajiban membayar zakat dan mereka yang menjadi mustahiq, mengalihkan, menyimpan dan menjaga serta menginvestasikan harta zakat sesuai dengan ketentuan yang ditetapkan dalam rekomendasi pertama seminar masalah zakat kontemporer internasional ke-3, di Kuwait. Lembaga-lembaga dan panitia-panitia pengurus zakat yang ada pada zaman sekarang ini adalah bentuk kontemporer bagi lembaga yang berwenang mengurus zakat yang ditetapkan dalam syari'at Islam.Oleh karena itu, petugas (amil) yang bekerja di lembaga tersebut harus memenuhi syarat-syarat yang ditetapkan.

\section{Pendidikan Formal}

Menurut Nawawi (1993), pendidikan formal adalah pendidikan yang dilakukan melalui jalur sekolah, baik itu pendidikan umum maupun pendidikan agama yang dimulai dari jenjang yang terendah sampai tertinggi, termasuk juga madrasah dan pesantren. Adapun fungsi pendidikan formal itu sendiri menurut Nawawi adalah sebagai berikut: a) Membantu mempersiapkan anak-anak agar menjadi anggota masyarakat yang memiliki pengetahuan, keterampilan dan keahlian yang dapat dipergunakannya untuk memperoleh nafkah hidupnya masing-masing. b)Membantu mempersiapkan anak-anak agar menjadi anggota masyarakat yang memiliki kemampuan memecahkan masalah kehidupan, baik masalah-masalah sebagai 
individu maupun masalah yang berhubungan dengan kebersamaan sebagai masyarakat dan bangsa. c) Membantu meletakkan dasar-dasar hubungan sosial yang harmonis dan manusiawi, agar anak-anak mampu mewujudkan realisasi dirinya secara bersama-sama di dalam masyarakat yang dilindungi Allah SWT dan d)Membantu anak-anak menjadi muslim, mukmin dan muttaqin, sesuai dengan tingkat perkembangan dan potensinya masing-masing.

Menurut Sikula dalam Mangkunegara (2003), tingkat pendidikan adalah suatu proses jangka panjang yang menggunakan prosedur sistematis dan terorganisir, yang mana tenaga kerja manajerial mempelajari pengetahuan konseptual dan teoritis untuk tujuantujuan umum.

\section{Pelatihan}

Pelatihan sangat penting bagi amil zakat, baik bagi amil yang baru saja bertugas maupun yang telah lama bertugas, program pelatihan memberikan kesempatan kepada amil untuk meningkatkan pengetahuannya terutama mengenai dimensi-dimensi zakat, serta apa-apa saja yang harus dilakukannya sebagai amil dan yang paling penting untuk mengetahui tanggung jawabnya secara utuh juga haknya sebagai amil. Pelatihan didefinisikan sebagai kegiatan yang dirancang untuk meningkatkan kinerja pekerja dalam pekerjaan yang diserahkan kepada mereka (Hardjana, 2001).

Menurut Hardjana (2001), dalam merancang pelatihan yang baik harus memperhatikan pihak-pihak yang terlibat dalam training (materi yang akan diterima peserta, waktu pelaksanaan danPemateri (trainer), tujuan yang akan dicapai, materi yang akan diolah, metode dan peralatan yang hendak dipakai tempat pelaksanaan, jadwal kegiatan untuk tiap sesi ataupun secara keseluruhan. Semua itu dirancang secara efisien, lancar dan efektif untuk mencapai tujuan training. Pada waktu merancang training hal-hal yang perlu dipertimbangkan adalah kebutuhan, tujuan, petugas, dan evaluasi training.

\section{Kinerja}

Secara umum pengertian kinerja adalah hasil pekerjaan yang mempunyai hubungan kuat dengan tujuan strategis organisasi, kepuasan, konsumen, dan memberikan kontribusi pada ekonomi sehingga seseorang berupaya untuk melakukan pekerjaan dan hasil yang dicapai dari pekerjaan tersebut. Kinerja harus dapat dikatakan sebagai apayang dikerjakan dan bagaimanacara mengerjakannya.

Kinerja bagi amil zakat pada umumnya menurut Metwally (1995) adalah melakukan pengumpulan zakat, mendoakannya kemudian membagikannya kepada masyarakat yang membutukan, sehingga apabila pengumpulan dana zakat lebih banyak dan pembagian dana zakat tersebut telah sampai kepada masyarakat yang sesuai, maka kinerja seorang amil dinyatakan baik.

\section{Hubungan Pendidikan Formal dan Kinerja}

Ihsan (1996), mengatakan bahwa pendidikan merupakan usaha manusia untuk menumbuhkan dan mengembangkan potensi-potensi pembawaan baik jasmani maupun rohani sesuai dengan nilai-nilai yang ada di dalam masyarakat dan kebudayaan. Atau dengan kata lain bahwa pendidikan dapat diartikan sebagai suatu hasil peradaban bangsa yang dikembangkan atas dasar pandangan hidup bangsa itu sendiri (nilai dan norma masyarakat) yang berfungsi sebagai filsafat pendidikannya atau sebagai cita-cita dan pernyataan tujuan pendidikannya. Selanjutnya, pendidikan adalah "usaha sadar yang dengan sengaja dirancangkan untuk mencapai tujuan yang telah ditetapkan". Menurut Nawawi (2003), pendidikan formal adalah pendidikan yang dilakukan melalui jalur sekolah, dari jenjang yang terendah sampai tertinggi, termasuk juga madrasah dan pesantren, pendidikan formal sering dikaitkan dengan pengetahuan seseorang sejauhmana dia memahami sesuatu dan mengerjakan sesuatu dengan pemahamannya serta sejauhmana prestasinya dalam menempuh pendidikan secara formal itu, seseorang yang tidak memiliki pendidikan baik itu pendidikan umum maupun pendidikan agama, tidak akan mampu melakukan sesuatu dengan baik terlebih lagi suatu pekerjaan yang membutuhkan pengetahuan khusus, pendidikan formal merupakan salah satu sarana seseorang untuk mendapatkan pengetahuan, belajar dan mengenali potensi diri, sejauhmana kemampuanya dalam memahami sesuatu dan mengaplikasikan pemahamannya tersebut. Pekerjaan apapun itu selalu membutuhkan keahlian didalamnya, seseorang yang tidak memiliki pengetahuan yang didapatkan melalui proses pendidikan tidak akan mampu untuk memahami pekerjaan dengan baik. 


\section{Hubungan Pelatihan Dan Kinerja}

Pelatihan adalah setiap usaha untuk memperbaiki performance pekerja pada suatu pekerjaan tertentu yang sedang menjadi tanggungjawabnya, atau suatu pekerjaan yang ada hubungannya dengan pekerjaannya, pelatihan ini akan sangat berguna untuk membantu seseorang dalam pekerjaanya, selama materi-materi yang diberikan pada saat pelatihan sesuai dan mengena pada pekerjaan yang sedang digeluti peserta. Dengan mengikuti pelatihan seseorang akan mendapatkan tambahan pengetahuan dan akan semakin mahir dalam menjalankan.

\section{Kerangka Pikir}

\section{Tabel 1. Kerangka Pikir Penelitian}

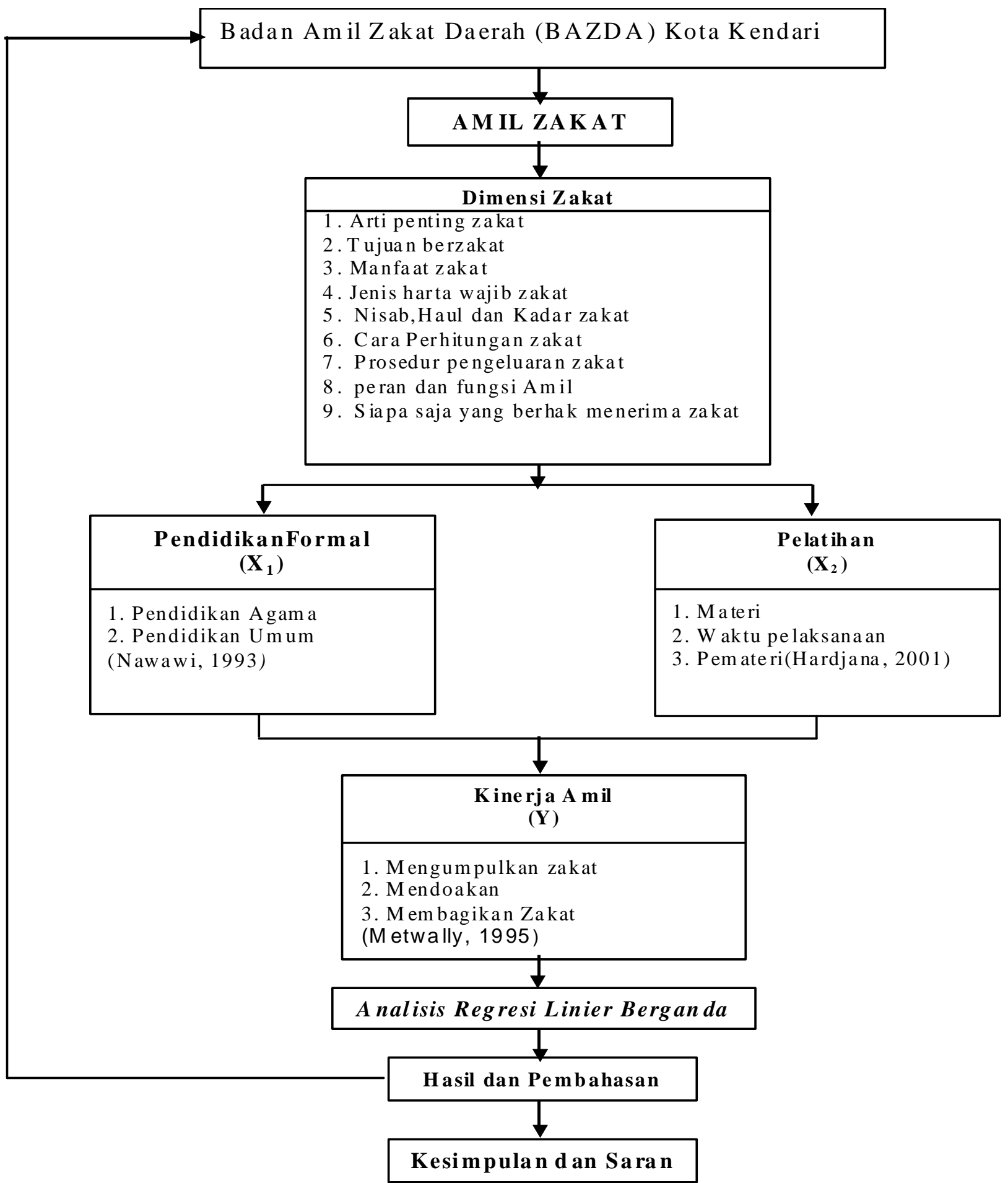




\section{Hipotesis}

Berdasarkan permasalahan dan kerangka konseptual yang telah dikemukakan, maka hipotesis penelitian ini yaitu: Ada pengaruh secara signifikan Pendidikan Formal dan Pelatihanterhadap Kinerja Amil Zakat di Kota Kendari”.

\section{METODE PENELITIAN}

Penelitian ini dilaksanakan di Tiga Kecamatan, diantaranya Kecamatan Puwatu, Kecamatan Wawombalata dan Kecamatan Abeli Kota Kendari, Provinsi Sulawesi Tenggara.Populasi penelitian ini adalah amil zakat yang ada di tiga Kecamatan yaitu Kecamatan Mandonga, Kecamatan Puwatu dan Kecamatan Abeli kota Kendari. Dari populasi yang ada diambil responden sebanyak 2 orang dari tiaptiap Kelurahan yang ada pada Kecamatan Puwatu, Wawombalata dan Abelidengan rincian, Kecamatan Puwatu yang terdiri dari 6 (Enam) Kelurahan sebanyak 12 Sampel, Kecamatan Wawombalata juga terdiri dari 6 Kelurahan sebanyak 12 Sampel dan untuk Kecamatan Abeli dengan memikirkan waktu tempat dan juga biaya, penulis hanya mengambil 20 respondenyang dianggap mampu mewakili dari 13 Kelurahan yang ada, sehingga didapatkan sebanyak 44 Responden sebagai sampel.

Jenis dan sumber data dalam penelitian ini adalah data primer yaitu yang berasal langsung dari sumber yang dikumpulkan secara khusus dan berhubungan langsung dengan permasalahan yang diteliti (Cooper dan Emory 1995dalam Andraeni 2006).Sumber data primer pada penelitian ini diperoleh langsung dari hasil jawaban responden dari seluruh item pertanyaan yang diajukan melalui kuesioner yang disi oleh para amil zakat yang ditetapkan sebagai Responden.

Teknik pengumpulan data dalam penelitian ini adalah metode angket, yaitu pengumpulan data dengan cara mengedarkan daftar pertanyaan tertulis (kuesioner) kepada amil zakat yang telah ditetapkan sebagai responden penelitian untuk mendapatkan data mengenai pendidikan, pelatihan, dan kinerja.

Skala pengukuran dalam penelitian ini, yaitu menggunakan skala likert dimana skala likert digunakan untuk mengukur sikap, pendapat dan persepsi seseorang atau sekelompok orang tentang fenomena sosial (Sugiyono, 2001).

\section{Definisi Operasional Variabel}

Variabel Pendidikan Formal $\left(\mathrm{X}_{1}\right)$ yaitu Pendidikan dalam arti praktek atau Suatu proses pemindahan pengetahuan ataupun pengembangan potensi-potensi yang dimiliki subjek didik untuk mencapai perkembangan secara optimal serta membudayakan manusia melalui proses tranformasi nilai-nilai yang utama. variabelpendidikan diukur melalui 2 (dua) indikator variabel dari teori yang dikemukakan oleh Nawawi, (1993), yaitu: a. Pendidikan Agama yaitu pendidikan pada lembaga-lembaga formal yang lebih menekankan pada pengetahuan keagamaannya, pendidikan mengenai zakat beserta dimensinya diharapkan didapatkan pada pendidikan agama ini, sehingga membantu amil melaksanakan kinerjanya $\left(X_{1,1}\right)$, b. Pendidikan Umum yaitu pendidikan pada lembaga-lembaga formal yang menekankan pada ilmu pengetahuan tentang sekitar dan tidak berpatok pada pendidikan agama saja,pendidikan umum ini diharapkan juga dapat membantu amil dalam kinerjanya kedepannya $\left(\mathrm{X}_{1,2}\right)$.

Variabel Pelatihan $\left(\mathrm{X}_{2}\right)$ Menurut Panggabean (2002), adalah sebagai suatu cara yang digunakan untuk memberikan atau meningkatkan keterampilan yang dibutuhkan untuk melaksanakan pekerjaannya sekarang, dengan mengikuti pelatihan amil dapat meningkatkan pengetahuannya khususnya mengenai zakat sehingga seorang amil memiiliki pengetahuan dan keterampilan dalam menjalankan tugasnya dan lebih memahami dimensi-dimensi zakat yang akan berpengaruh pada hasil kerjanya dimasa depan. Variabel pelatihan ini memiliki 3 (tiga) indikator menurut Hardjana (2001) yang meliputi: a. Materi pelatihan: yaitu bahan ajar yang digunakan oleh pemateri pada saat melaksanakan pelatihan, materi yang ada harus benar-benar sesuai dengan kondisi dan pekerjaan yang sedang digeluti oleh para peserta, dalam hal ini amil zakat $\left(\mathrm{X}_{2.1}\right)$. b. Waktu pelaksanaan pelatihan: Yaitu kesesuaian waktu dengan materi yang akan disajikan, apakah waktu yang disediakan sudah memadai untuk penguasaan materi yang ada. $\left(\mathrm{X}_{2.2}\right)$. c. Pemateri: kemampuan pemateri dalam memberikan materinya semakin baik cara pemateri menyampaikannya, akan semakin mudah diserap oleh peserta pelatihan $\left(\mathrm{X}_{2.3}\right)$.

Variabel Kinerja (Y) Menurut Handoko (2002) adalah hasil kerja yang dicapai seseorang dalam melaksanakan tugas-tugas yang dibebankan kepadanya yang didasarkan atas kecakapan, pengalaman dan kesungguhan waktu. Variabel ini dapat diukur dengan Tiga item yang diadaptasi dari Metwally (1995) yang meliputi: mengumpulkan zakat: Mengumpulkan zakat dari masyarakat merupakan tugas utama seorang amil, semakin banyak dana yang terkumpul 
menandakan kinerja amil tersebut baik $\left(\mathrm{Y}_{11}\right)$, mendoakan muzakki (orang yang membayar zakat): Hal ini juga sudah menjadi tugas para amil, dimana pada saat muzakki membayar zakat saat itulah amil melaksanakan kinerjanya dengan mendoakannya $\left(\mathrm{Y}_{1.2}\right)$ dan membagikan zakat: Yaitu dengan melihat kondisi masyarakat yang ada disekitarnya kemudian memilahmilah siapa saja yang berhak menerima zakat, ketepatan sasaran pemberian dana zakat tersebut dan mampu meringankan beban penerima membuktikan bahwa amil telah melaksanakan kinerjanya dengan baik $\left(\mathrm{Y}_{1.3}\right)$.

\section{Metode Analisis Data}

Berdasarkan tujuan yang ingin dicapai dalam penelitian ini, maka data yang diperoleh akan diolah dan dipaparkan berdasarkan statistic deskriptif. Selanjutnya untuk kepentingan analisis dan pengujian hipotesis digunakan analisis regresi linier berganda. Untuk menguji hipotesis pengaruh variabel bebas $\left(\mathrm{X}_{\mathrm{i}}\right)$ secara bersama-sama terhadap variabel terikat $(\mathrm{Y})$ digunakan uji $F$. Jika $F_{\text {sig }}<\alpha_{0,05}$ maka ada pengaruh nyata variabel bebas terhadap variabel terikat. Demikian pula sebaliknya, jika $\mathrm{F}_{\text {sig }}>\alpha_{0,05}$ maka tidak ada pengaruh nyata variabel bebas terhadap variabel terikat. Sedangkan untuk menguji pengaruh variabel bebas $\left(\mathrm{X}_{\mathrm{i}}\right)$ secara parsial digunakan uji t. Apabila $\mathrm{t}_{\mathrm{sig}}<\alpha_{0,05}$ maka variabel bebas tersebut berpengaruh nyata terhadap variabel terikat. Demikian pula sebaliknya, apabila $\mathrm{t}_{\mathrm{sig}}>\alpha_{0,05}$ maka variabel bebas tersebut tidak berpengaruh nyata terhadap variabel terikat.

\section{Hasil Pengujian Hipotesis}

Untuk membuktikan hipotesis penelitian yang diajukan dalam penelitian ini, digunakan metode regresi linear berganda dengan hasil analisis sebagai berikut:

Tabel 2. Hasil Analisis Regresi Berganda Pengaruh Pendidikan Formal dan Pelatihan terhadap Kinerja Amil Zakat di Kota Kendari

\begin{tabular}{|c|c|c|c|c|c|}
\hline \multicolumn{2}{|c|}{ Variabel Bebas } & Koefisien Regresi & t Hitung & \multicolumn{2}{|c|}{ t Signifikan } \\
\hline \multirow{2}{*}{\multicolumn{2}{|c|}{$\begin{array}{l}\mathrm{X}_{1} \\
\mathrm{X}_{2}\end{array}$}} & .686 & 5,890 & & .000 \\
\hline & & .253 & 2,170 & & .036 \\
\hline Konstanta $\mathrm{B}_{0}$ & & dengan t signifikan 3 & & & \\
\hline R Square & $=$ & 0,819 & & $\mathrm{~N}$ & $=44$ \\
\hline $\mathrm{R}$ & & 0,905 & & $\alpha$ & $=0,05$ \\
\hline F hitung & $=$ & 92,892 & & & \\
\hline F singnifikan & $=$ & 0,000 & & & \\
\hline Standar error & & 2,21824 & & & \\
\hline
\end{tabular}

Berdasarkan hasil perhitungan regresi seperti pada Tabel 1 tersebut maka model regresi yang dihasilkan dapat dinyatakan sebagai berikut:

$\mathrm{Y}=0,686 \mathrm{X}_{1}+0,253 \mathrm{X}_{2}+2,21824$

Di mana:

$\begin{array}{ll}\mathrm{Y} & =\text { Kinerja Amil } \\ \mathrm{X}_{1} & =\text { Pendidikan Formal } \\ \mathrm{X}_{2} & =\text { Pelatihan }\end{array}$

e (standar error $)=2,21824$

Dari Tabel di atas, dapat diketahui bahwa Nilai $\mathrm{F}_{0,05}=92,892$ dengan nilai signifikansi sebesar $\mathrm{F}_{\text {sig }}=$ 0,000 yang berarti bahwa $\left(\mathrm{F}_{\text {sig }}<0,05\right)$, maka secara statistika variabel Pendidikan Formal yang meliputi Pendidikan Agama $\left(\mathrm{X}_{1}\right)$ dan Pendidikan Umum $\left(\mathrm{X}_{2}\right)$ secara simultan (bersama) berpengaruh signifikan terhadap Kinerja Amil (Y) pada taraf kepercayaan $95 \%$. Nilai $\mathrm{R}^{2}(R$-Square) sebesar 0,819 menunjukkan besaran pengaruh secara simultan $\mathrm{X}_{1}, \mathrm{X}_{2}$ terhadap $\mathrm{Y}$ adalah $81,9 \%$ atau berarti model yang digunakan $X_{1}$ (Pendidikan Formal) dan $\mathrm{X}_{2}$ (Pelatihan) mampu menjelaskan Y (Kinerja Amil) sisanya sebesar 18,1\% dijelaskan di luar model penelitian.

Nilai R (angka koefisien korelasi) sebesar 0,905, menunjukkan bahwa keeratan hubungan secara simultan antara $X_{1}, X_{2}$, dengan $Y$ adalah sebesar 0,901 . Hubungan ini secara statistika tergolong sangat erat, sebagaimana yang dikemukakan oleh Sugiono (1999) bahwa hubungan yang tergolong kuat adalah sebesar 0,60 - 0,79 sedangkan yang tergolong sangat kuat sebesar 0,80 - 1,000. Oleh karena itu, model regresi yang dihasilkan dapat dikatakan sebagai model yang "Fit" atau dapat menjadi model penduga yang baik dalam menjelaskan pengaruh Pendidikan Formal dan Pelatihan terhadap Kinerja Amil Zakat.

Pengujian secara parsial dari tabel di atas, dapat diinterpretasikan sebagai berikut: Signifikansi pengaruh variabel $\mathrm{X}_{1}$ Pendidikan Formal terhadap Y (Kinerja

Sumber: Hasil perhitungan tahun 2013 
Amil) diperoleh nilai $\mathrm{t}_{\text {hitung }}\left(\mathrm{t}_{0.05}=5,890\right)$, dengan nilai signifikansi sebesar $\mathrm{t}_{\text {sig }} 0,000$ yang berarti lebih kecil dari nilai $\alpha=0,05$. hal ini mengindikasikan bahwa Pendidikan Formal $\left(\mathrm{X}_{1}\right)$ secara parsial berpengaruh terhadap Kinerja Amil (Y). Atas dasar itu pula sehingga variabel $\mathrm{X}_{1}$ (Pendidikan Formal) dapat dimasukkan sebagai salah satu variabel penduga bagi Kinerja Amil Zakat di Kota Kendari khususnya pada 3 Kecamatan (Puwatu, Wawombalata, dan Abeli).

Signifikansi pengaruh variabel $\mathrm{X}_{2}$ (Pelatihan) terhadap Y (Kinerja Amil) diperoleh nilai $\mathrm{t}_{\text {hitung }}\left(\mathrm{t}_{0,05}=\right.$ 2,170 ), dengan nilai signifikansi sebesar $\mathrm{t}_{\text {sig }}=0,036$ yang berarti lebih kecil dari nilai $\alpha=0,05$. hal ini mengindikasikan bahwa Pelatihan $\left(\mathrm{X}_{2}\right)$ secara parsial berpengaruh terhadap Kinerja Amil (Y). Atas dasar itu pula sehingga variabel $\mathrm{X}_{2}$ (Kinerja Amil) dapat dimasukkan sebagai salah satu variabel penduga bagi Kinerja Amil Zakat di Kota Kendari khususnya pada 3 Kecamatan (Puwatu, Wawombalata dan Abeli).

Hipotesis penelitian yang perlu diuji adalah Kinerja Amil yang terdiri dari Pendidikan Formal $\left(X_{1}\right)$, Pelatihan $\left(\mathrm{X}_{2}\right)$, berpengaruh signifikan terhadap Kinerja Amil Zakat (Y) di Kota Kendari khususnya pada 3 Kecamatan (Puwatu, Wawombalata dan Abeli). Hasil uji simultan dengan menggunakan nilai $\mathrm{F}_{\text {hitung }}$ pada taraf $\alpha=0,05$ sebesar 92,892 $\left(\mathrm{F}_{0,05}=\right.$ $92,892)$, dan nilai $\mathrm{F}_{\text {sig }}$ sebesar $0,000\left(\mathrm{~F}_{\text {sig }}=0,000\right)$ berarti nilai $\mathrm{F}_{\text {sig }}<0,05$. Karena itu, secara keseluruhan atau secara bersama-sama variabel Pendidikan Formal $\left(X_{1}\right)$, Pelatihan $\left(X_{2}\right)$ berpengaruh signifikan terhadap Kinerja Amil (Y) Kota Kendari. Atas dasar ini, maka hipotesis penelitian yang diajukan sebelumnya dapat diterima karena terbukti kebenarannya.

\section{KESIMPULAN DAN SARAN}

\section{Kesimpulan}

Berdasarkan hasil analisis dan pembahasan yang diperoleh, maka dapat diajukan kesimpulan sebagai berikut: a) secara simultan terdapat pengaruh yang signifikan variabel pendidikan Pendidikan Formal dan pelatihan terhadap kinerja Amil zakat Kota Kendari (Kecamatan Puwatu, Kecamatan Wawombalata dan Kecamatan Abeli). b) Secara parsial dari variabel pendidikan formal dan pelatihan memiliki hubungan dan pengaruh yang signifikan terhadap kinerja Amil zakat pada Amil zakat (Kecamatan Puwatu, Kecamatan Wawombalata dan Kecamatan Abeli) Kota Kendari.

\section{Saran}

Berdasarkan kesimpulan yang diperoleh, maka dapat diajukan saran atau rekomendasi sebagai berikut: a) Untuk meningkatkan kinerja Amil zakat maka yang harus diperhatikan oleh pimpinan BAZDA (Badan Amil Zakat Daerah) Kota Kendari atau pemerintah adalah memperhatikan latar belakang pendidikan seorang amil yang tentunya harus sesuai dengan profesi atau tugas yang dikerjakan dan adanya pemberian pelatihan kepada Amil zakat yang merupakan bagian dari proses pendidikan yang ditujukan untuk meningkatkan kemampuan atau keterampilan khusus para amil karena dapat membantu meningkatkan kinerja Amil zakat. b) Bagi peneliti selanjutnya, untuk memperoleh penjelasan yang lebih komprehensif tentang pengaruh jenis pendidikan dan pelatihan, maka dalam penelitian berikutnya disarankan agar dapat mengembangkan dimensi variabel yang lain dan sebagai bahan referensi bagi peneliti selanjutnya yang diharapkan lebih memperluas lagi dari penelitian sebelumnya baik variabel maupun objek yang diteliti.

\section{DAFTAR RUJUKAN}

Al-Quran dan Terjemahnya. 2005. Bandung: PT Syamil Media Cipta.

Andraeni, N. 2006. "Pengaruh Stress Kerja Terhadap Motivasi Kerja dan Kinerja Keryawan Pada PT. H.M Sampoerna Tbk Surabaya”. Skripsi, Universitas Airlangga.

Handoko, T.H. 2002. Manajemen Personalia dan Sumber Daya Manusia. Yogyakarta: BPFE.

Hardjana. 2001. Kiat Sukses di Perguruan Tinggi. Yogyakarta: Kanisius.

Ihsan, F. 1996. Filsafat Ilmu. Jakarta: Rineka Cipta.

Mangkunegara, A.P. 2003. Perencanaan \& Pengembangan Sumber Daya Manusia. Bandung: PT Refika Aditama.

Metwally. 1995.Teori dan Model Ekonomi Islam. Jakarta: Bakti Daya Insani.

Nawawi, H.H. 2003. Perencanaan Sumber Daya Manusia; untuk Organisasi Profit yang Kompetitif. Yogyakarta: Gajah Muda University Press.

Panggabean. 2002. Manajemen Sumber Daya Manusia Bogor: Ghalia Indonesia.

Sadili, S. 2006. Manajemen Sumber Daya Manusia. Bandung: CV Pustaka.

Sedarmayanti. 2001. Sumber Daya Manusia dan Produktivitas Kerja. Bandung: Mandar Maju.

Sodikin, R. 2006," Pengaruh pelatihan terhadap Produktivitas Karyawan di PT Gunung Madu Plantations”. Skripsi,Universitas Gajahmada. 
Wahyuniati, Hamid

Sugiyono. 2001, “Metode Penelitian”. Bandung: Penerbit CV Alfabeta.

Syafei. 2006. Studi Analisis Faktor Kinerja Petugas di Kota Jambi. Yogyakarta: Universitas Gajah Mada.
Tafsir, A. 1992. Ilmu pendidikan dalam Perspektif Islam, Bandung: PT Remaja Rosdakarya. 